\title{
Comparação de três protocolos distintos para extração de RNA de amostras fixadas em formalina e emblocadas em parafina
}

\author{
Comparison of three different protocols for extracting RNA from formalin-fixed paraffin-embedded tissues
}

Gisele Rodrigues Gouveia'; Suzete Cleusa Ferreira²; Ester Cerdeira Sabino³; Sheila Aparecida Coelho Siqueira ${ }^{4}$; Juliana Pereira ${ }^{5}$

abstract

Introduction: Formalin fixed paraffin embedded (FFPE) tissues are an important sample source for retrospective studies. Despite its ability to preserve proteins and cell morphology, formalin hinders Molecular Biology tests once it fragments and chemically modifies nucleic acids, particularly RNA. Objective: To compare the efficiency of three different RNA extraction protocols for gene expression analysis of FFEP tissues. Material and methods: RNA was extracted from FFPE samples of human lymph by means of Ambion and Arcturus Bioscience kits and the classical Trizol method. After extraction, RNA was quantified and tested for amplification through real time polymerase chain reaction (RT-PCR) using glyceraldehydes-3 phosphate dehydrogenase (GAPDH) endogenous gene primers. Discussion/conclusion: All the protocols produced sufficient and adequate amounts of total RNA. However, only protocols using Arcturus and Ambion kits generated suitable RNA for PCR amplification.
Primeira submissão em 13/03/11 Última submissão em 15/06/11 Aceito para publicação em 16/06/11 Publicado em 20/12/11

\begin{tabular}{l|l}
\multicolumn{1}{c|}{ Unitermos } & reSU MO \\
\hline Tecidos & $\begin{array}{l}\text { Introdução: Tecidos fixados em formalina e emblocados em parafina (FFEP) são importantes fontes de } \\
\text { amostras para estudos retrospectivos. Apesar de sua capacidade de preservação de proteínas e morfologia } \\
\text { Formalina }\end{array}$ \\
$\begin{array}{l}\text { Parafina } \\
\text { RNA }\end{array}$ & $\begin{array}{l}\text { quimicamente os ácidos nucleicos, particularmente o ácido ribonucleico (RNA). Objetivo: Comparar a } \\
\text { eficiência de três diferentes protocolos de extração de RNA para análise de expressão gênica de tecidos } \\
\text { FFEP. Material e métodos: Amostras de linfonodo humano FEEP foram submetidas à extração de RNA } \\
\text { utilizando-se os kits Ambion e Arcturus Bioscience e o método clássico de Trizol. Após a extração, o RNA } \\
\text { foi quantificado e testado quanto à sua capacidade de amplificação pela reação em cadeia da polimerase } \\
\text { em tempo real (RT-PCR) utilizando primers do gene endógeno gliceraldeído-3 fosfato desidrogenase } \\
\text { (GAPDH). Discussão/conclusão: Todos os protocolos testados produziram quantidades adequadas } \\
\text { e suficientes de RNA total, entretanto, somente os protocolos com uso dos kits Ambion e Arcturus } \\
\text { produziram RNA capaz de ser amplificado pela PCR. }\end{array}$
\end{tabular}

key words

\section{Tissues}

Formalin

Paraffin

RNA

Gene expression

\footnotetext{
1. Especialização em Hematologia; técnica de laboratório; mestranda da Faculdade de Medicina da Universidade de São Paulo (FMUSP).

2. Mestra em Ciências pela FMUSP; biologista do Departamento de Biologia Molecular da Fundação Pró-Sangue do Hemocentro de São Paulo.

3. Livre-docente da disciplina de Hematologia da FMUSP; chefe do Departamento de Biologia Molecular da Fundação Pró-Sangue do Hemocentro de São Paulo.

4. Doutora em Patologia da USP; médica do Serviço de Patologia do Hospital das Clínicas (HC) da FMUSP.

5. Livre-docente da disciplina de Hematologia da FMUSP; coordenadora de Hematologia do Instituto do Câncer do Estado de São Paulo (ICESP); médica assistente do Serviço de Hematologia do Instituto Central (IC) do HC/FMUSP.
} 


\section{Introdução}

Tecidos fixados em formalina e emblocados em parafina (FFEP) são importantes fontes de amostras para estudos retrospectivos ${ }^{(8)}$. Estudos de expressão gênica de células malignas e microambiente tumoral têm contribuído para o entendimento da patogênese e do prognóstico das doenças, assim como para aperfeiçoar a classificação das mesmas ${ }^{(1,6)}$.

A fixação em formalina é o método mais utilizado na preservação de tecidos para estudos de anatomia patológica. É custo-efetiva, de fácil manuseio, preserva as características morfológicas celulares adequadamente e tem compatibilidade com os anticorpos utilizados em reações de imuno-histoquímica ${ }^{(6)}$. Entretanto, a formalina interfere na qualidade e na integridade estrutural e química dos ácidos nucleicos, sobretudo o ácido ribonucleico (RNA) ${ }^{(3,8)}$. As condições de tempo, a temperatura e o tipo de fixador influenciam na preservação desses ácidos. Fixações em formalina acima de uma semana induzem ligações cruzadas entre ácidos nucleicos, proteínas e outros componentes teciduais produzindo ácidos nucleicos fragmentados e resistentes à extração ${ }^{(3,6)}$.

Usualmente, o RNA mensageiro (RNAm), obtido por extração de amostras FFEP, encontra-se fragmentado em unidades com número de pares de bases inferior a $300^{(7)}$. Contudo, Hamatani et al. observaram que $80 \%$ das amostras de RNA de até 60 pares de bases podem ser amplificadas adequadamente pela reação em cadeia da polimerase $(P C R)$, mesmo com RNA extraído de amostra armazenada por longo tempo ${ }^{(4)}$.

Em geral, a degradação do RNA se inicia imediatamente após a retirada do material por ação das ribonucleases (RNAses) do meio ambiente. Subsequentemente, em virtude da fixação em formalina ocorrem modificações químicas secundárias às ligações cruzadas entre RNA e proteínas. Além disso, grupos monometilol são adicionados ao grupo amino nas bases nitrogenadas, principalmente na adenina, reduzindo a eficiência da amplificação do $\mathrm{RNA}^{(3,8)}$. A contaminação da amostra também é crítica para a qualidade do RNA. É necessária a higienização do ambiente de trabalho e dos instrumentos utilizados, desde a execução dos cortes dos blocos de parafina até a extração do RNA, os quais não devem conter RNAses ${ }^{(6)}$.

A primeira extração de RNA de amostras FFEP bem sucedida foi descrita por Rupp e Lucker em 1988. No entanto, ainda não há consenso acerca do melhor procedimento de extração de RNA com qualidade suficiente para estudos de biologia molecular ${ }^{(8)}$. A maioria dos protocolos envolve procedimentos básicos, como obtenção dos cortes com micrótomo descontaminado e desparafinização com sucessivos banhos de xilol e reidratação com etanol.

A desparafinização incompleta resulta em RNA de baixa qualidade. Entretanto, Lehmann e Kreipe ${ }^{(6)}$ observaram que a omissão dessa etapa evita a degradação e a contaminação do RNA. A proteinase $\mathrm{K}$ é usada para degradar proteínas ligadas aos ácidos nucleicos e a incubação entre $60^{\circ} \mathrm{C} \mathrm{e}$ $70^{\circ} \mathrm{C}$ remove os grupos metilol que foram adicionados pela formalina. $\mathrm{O}$ isolamento do RNA por agente desnaturante impede a ação das RNAses e a incubação com desoxirribonuclease (DNAse) é necessária para remover o ácido desoxirribonucleico (DNA) da amostra. Ao final, a purificação do RNA por precipitação com álcool em coluna porosa remove possíveis resíduos e contaminantes ${ }^{(8)}$.

\section{Objetivo}

Comparar a eficiência de três diferentes protocolos de extração de RNA para análise de expressão gênica de amostras fixadas em formalina e emblocadas em parafina.

\section{Material e métodos}

\section{Preparo das amostras}

Foram utilizadas amostras de linfonodo humano, selecionadas ao acaso, provenientes do arquivo do Serviço de Anatomia Patológica do Hospital das Clínicas da Faculdade de Medicina da Universidade de São Paulo (HC/FMUSP). Todas as amostras foram FFEP, e destas obtiveram-se três cortes de espessura de $10 \mu \mathrm{m}$ com micrótomo convencional. Os cortes foram colocados em tubos de eppendorf de $1,5 \mathrm{ml}$ desprovidos de RNAses e armazenados em temperatura ambiente (TA) até o momento da extração de RNA.

\section{Extração de RNA}

Cada protocolo de extração do RNA foi realizado de acordo com as instruções do fabricante em condições e equipamentos adequados, livres de RNAses, conforme Tabela 1.

\section{Protocolo 1: kit RecoverAll Total Nucleic Acid Isolation Optimized for FFPE Samples (Ambion, Inc, Austin, Texas, EUA)}

Inicialmente, realizou-se a desparafinização das amostras adicionando $1 \mathrm{ml}$ de xilol (Invitrogen, UK), incubando por 5 minutos a $50^{\circ} \mathrm{C}$, seguido de centrifugação por 5 minutos em velocidade máxima. Desprezou-se o sobrenadante lavando 


\section{Tabela 1 Resumo dos procedimentos dos protocolos}

\begin{tabular}{|c|c|c|c|}
\hline Procedimentos & Protocolo 1 & Protocolo 2 & Protocolo 3 \\
\hline Desparafinização & $\begin{array}{l}1 \mathrm{ml} \text { de xilol por } \\
3 \text { minutos a } 50^{\circ} \mathrm{C}\end{array}$ & $\begin{array}{l}\text { Três lavagens com } 1 \mathrm{ml} \\
\text { de xilol por } 3 \text { minutos } \\
\text { em TA }\end{array}$ & $\begin{array}{l}\text { Duas lavagens em xilol por } 5 \text { minutos } \\
\text { a } 57^{\circ} \mathrm{C} \text { em TA }\end{array}$ \\
\hline Reidratação & $\begin{array}{l}\text { Duas lavagens em } 1 \mathrm{ml} \\
\text { de etanol } 100 \%\end{array}$ & NR & $\begin{array}{l}\text { Lavagens em } 1 \mathrm{ml} \text { de etanol } 100 \% \text {, } \\
90 \% \text { e } 75 \% \text { ou apenas etanol } 100 \%\end{array}$ \\
\hline $\begin{array}{l}\text { Digestão com } \\
\text { proteinase K }\end{array}$ & $\begin{array}{l}\text { Tampão de digestão + } \\
\text { proteinase } \mathrm{K} \text { do kit por } \\
15 \text { minutos a } 50^{\circ} \mathrm{C} \text { e } \\
15 \text { minutos a } 80^{\circ} \mathrm{C}\end{array}$ & $\begin{array}{l}\text { Tampão de digestão } \\
\text { contendo proteinase } \mathrm{K} \text { do } \\
\text { kit por } 20 \text { horas a } 37^{\circ} \mathrm{C}\end{array}$ & $\begin{array}{l}\text { Tampão de digestão cotendo } \mathrm{NaCl} \text {, } \\
\text { Tris, EDTA, SDS } 1 \% \text { e proteinase } \mathrm{K} \text { por } \\
3 \text { horas a } 55^{\circ} \mathrm{C} \text { ou overnight a } 45^{\circ} \mathrm{C} \\
\text { com ou sem inativação da proteinase } \\
\mathrm{K} \text { a } 100^{\circ} \mathrm{C} \text { por } 7 \text { minutos }\end{array}$ \\
\hline Isolamento do RNA & $\begin{array}{l}\text { Lavagens sucessivas com } \\
\text { tampões contendo etanol } \\
\text { e colunas de purificação } \\
\text { do kit }\end{array}$ & $\begin{array}{l}\text { Lavagens sucessivas com } \\
\text { tampões contendo etanol } \\
\text { e colunas do kit }\end{array}$ & Método do Trizol \\
\hline $\begin{array}{l}\text { Tratamento com } \\
\text { DNAse }\end{array}$ & 30 minutos em TA & $\begin{array}{l}15 \text { minutos a } 37^{\circ} \mathrm{C} \mathrm{e} \\
1 \text { minuto a } 4^{\circ} \mathrm{C} \text { seguido } \\
\text { de inativação com DNAse } \\
10 \text { minutos a } 70^{\circ} \mathrm{C} \mathrm{e} \\
1 \text { minuto a } 4^{\circ} \mathrm{C}\end{array}$ & NR \\
\hline Purificação do RNA & $\begin{array}{l}\text { Lavagens com tampões } \\
\text { do kit e eluição }\end{array}$ & NR & NR \\
\hline
\end{tabular}

TA: temperatura ambiente; NR: etapa não realizada; EDTA: ácido etilenodiaminotetracético; SDS: dodecil sulfato de sódio.

duas vezes com $1 \mathrm{ml}$ de etanol absoluto para reidratação. As proteínas ligadas ao RNA foram degradadas com $200 \mu \mathrm{l}$ de tampão de digestão e $5 \mu \mathrm{l}$ de protease, seguido de incubação por 15 minutos a $50^{\circ} \mathrm{C}$ e 15 minutos a $80^{\circ} \mathrm{C}$. A seguir, realizou-se isolamento do RNA com adição de $790 \mu$ l de solução tampão contendo etanol absoluto e posterior passagem em coluna de separação. Após a lavagem das reações com os dois tampões do kit, realizou-se tratamento com DNAse, nova lavagem e eluição do RNA com $60 \mu \mathrm{l}$ do tampão de eluição do kit em TA, de acordo com as instruções do fabricante.

\section{Protocolo 2: kit Paradise ${ }^{\circledR}$ Whole Transcript RT Reagent System (Arcturus Bioscience, Inc, Mountain View, Califórnia, EUA)}

Após desparafinização com três lavagens em $1 \mathrm{ml}$ de xilol (Invitrogen, UK) por 3 minutos em TA, a amostra foi incubada com solução tampão de proteinase $K$ por 20 horas a $37^{\circ} \mathrm{C}$ para digestão das proteínas. Em seguida, o RNA foi isolado por sucessivas lavagens com solução tampão do kit contendo etanol e passagem das amostras na coluna de purificação, conforme instruções do fabricante. Depois, as amostras foram incubadas com soluções tampão contendo DNAse a $37^{\circ} \mathrm{C}$ por 15 minutos e a $4^{\circ} \mathrm{C}$ por 1 minuto. Posteriormente, a DNAse foi inativada incubando-se as amostras por 10 minutos a $70^{\circ} \mathrm{C}$ e por 1 minuto a $4^{\circ} \mathrm{C}$.

\section{Protocolo 3: Método de extração em Trizol (Invitrogen, UK)}

Para extração do RNA pelo método do Trizol, testaram-se diferentes possibilidades, conforme Körbler et al.(5). A desparafinização realizou-se lavando a amostra duas vezes com $1 \mathrm{ml}$ de xilol (Invitrogen, UK) ou pela incubação com xilol por 5 minutos a $57^{\circ} \mathrm{C}$ ou por 15 minutos em TA. As amostras foram centrifugadas por 2 minutos com velocidade máxima entre as incubações.

Durante a reidratação, algumas amostras foram lavadas sucessivamente em etanol $100 \%, 90 \%$ e $75 \%$ e centrifugadas por 10 minutos em TA com velocidade máxima, enquanto outras foram lavadas apenas com etanol absoluto. A digestão foi realizada incubando-se as amostras em solução tampão contendo $\mathrm{NaCl} 10 \mathrm{mM}$, Tris pH 7,6500 mM, ácido etilenodiaminotetracético (EDTA) $20 \mathrm{mM}$, dodecil sulfato de sódio (SDS) $1 \%$ e proteinase $\mathrm{K} 500 \mu \mathrm{g} / \mathrm{ml}$ de formas diferentes: na primeira, a amostra foi incubada a $55^{\circ} \mathrm{C}$ por 
3 horas e na segunda a $45^{\circ} \mathrm{C}$ overnight com ou sem inativação da proteinase $\mathrm{K}$ pela elevação da temperatura a $100^{\circ} \mathrm{C}$ por 7 minutos. Ao final, todas as amostras foram submetidas à extração de RNA pelo método de Trizol, conforme descrito previamente por Chomczynski e Sacchi(2).

\section{Avaliação da quantidade e da qualidade do RNA extraído}

A concentração e a pureza do RNA extraído foram avaliadas no equipamento NanoDrop (NanoDrop Technologies, Inc., Wilmington, DE). Considerou-se adequadas as quantidades de RNA acima de $50 \mathrm{ng} / \mu \mathrm{l}$ com grau de pureza entre 1,7 e 1,9.

\section{Transcrição reversa (cDNA)}

Para síntese de cDNA, adicionou-se $2 \mu \mathrm{l}$ de Randon Primer em $10 \mu \mathrm{l}$ da amostra do RNA previamente extraído, com posterior aquecimento a $70^{\circ} \mathrm{C}$ por 10 minutos, seguido de repouso por 5 minutos a $45^{\circ} \mathrm{C}$ para resfriamento. Adicionou-se $8 \mu$ da solução Mix contendo $4 \mu$ de tampão $5 x ; 1 \mu$ de DL-ditiotreitol (DTT) ; $1 \mu \mathrm{l}$ de desoxirribonucleotídeos fosfatados (DNTP) 10x; 0,5 $\mu$ de Super Script; $0,5 \mu \mathrm{l}$ de inibidor de RNAse e $1 \mu \mathrm{l}$ de água dietilpirocarbonato (DEPC) em cada amostra, incubando-as a $45^{\circ} \mathrm{C}$ overnight. Ao final, as amostras foram homogeneizadas e deixadas por 10 minutos a $70^{\circ} \mathrm{C}$ com sequencial armazenamento em temperatura de $-20^{\circ} \mathrm{C}$ ou $-80^{\circ} \mathrm{C}$.

\section{PCR em tempo real (RT-PCR)}

A RT-PCR foi realizada com o sistema TaqMan Universal PCR Master Mix (Applied Biosystems, EUA). Para tanto, foram misturados 12,5 $\mu$ l de Master Mix 2x; 1,25 $\mu$ l do primer 20x; $10 \mu \mathrm{l}$ da amostra de cDNA e 1,25 $\mu \mathrm{l}$ de água DEPC. Como controle positivo, utilizou-se o primer GAPDH, marcado com sonda VIC-TAMRA (Applied Biosystems, EUA), e como negativo, água DEPC. A amplificação foi realizada no aparelho
iCycler da BioRad, sendo o primeiro ciclo $(1 \times)$ a $95^{\circ} \mathrm{C}$ por 10 minutos e o segundo ciclo $(45 \times)$, a $95^{\circ} \mathrm{C}$ por 15 segundos e a $60^{\circ} \mathrm{C}$ por 1 minuto. A leitura foi realizada em FAM-490.

\section{Resultados}

Os RNAs obtidos pelos três protocolos utilizados apresentaram concentrações e pureza adequadas, de acordo com a Tabela 2.

$\mathrm{Na}$ RT-PCR, todos os controles utilizados foram negativos e a curva padrão apresentou linha de amplificação adequada. Porém, somente as amostras processadas pelos protocolos 1 (Ambion) e 2 (Arcturus Bioscience) permitiram a amplificação do RNAm do gene endógeno GAPDH; os valores de Cycle Threshold $(\mathrm{Ct})$ médios variaram entre 30 e 31,1 (Tabela 3 e Figura ).

No protocolo 2, a concentração média das amostras de RNA eluídas em $12 \mu \mathrm{l}$ (conforme protocolo estabelecido pelo kit) foi muito elevada $(631,8 \mathrm{ng} / \mu \mathrm{l})$. Optamos por realizar uma segunda eluição em $50 \mu$ de água DEPC para verificar se o excesso de RNA poderia interferir na amplificação por RT-PCR. O mesmo racional foi utilizado para as amostras extraídas pelo método do Trizol, porém não foram observadas diferenças na amplificação.

\section{Discussão}

Neste estudo demonstramos que a extração de RNA de FEEP, utilizando os protocolos 1 e 2 , foi eficiente quanto à capacidade de produzir RNA em quantidade e qualidade adequadas para análise de expressão gênica. Por outro lado, o método de Trizol, tradicionalmente utilizado para extração de RNA de amostras frescas, não produziu resultados satisfatórios.

\section{Tabela 2 Concentração e grau de pureza médios das amostras de RNA}

\section{Protocolo}

1. Kit RecoverAll Total Nucleic Acid Isolation Optimized for FFPE Samples

2. Kit Paradise ${ }^{\circledR}$ Whole Transcript RT Reagent System

3. Trizol Reagent
Concentração média de RNA (ng/ul)

58,7

Eluído em $12 \mu$ :

631,8

Eluído em $50 \mu$ :

202,6
Grau de pureza médio do RNA (relação 260/280 nM)

348,05 1,8 
Tabela 3 Valores Ct médios da RT-PCR para a expressão do gene GAPDH

\begin{tabular}{lc}
\hline Protocolo & Valor Ct médio \\
\hline 1. Kit RecoverAll Total Nucleic Acid Isolation Optimized for FFPE Samples & 30 \\
\hline 2. Kit Paradise ${ }^{\circledR}$ Whole Transcript RT Reagent System & Eluído em $12 \mu l: 31,1$ \\
\hline 3. Trizol Reagent & Eluído em $50 \mu l: 30,3$ \\
\hline
\end{tabular}

Ct: Cycle Threshold; RT-PCR: reação em cadeia da polimerase em tempo real; GAPDH: gliceraldeído-3 fosfato desidrogenase.

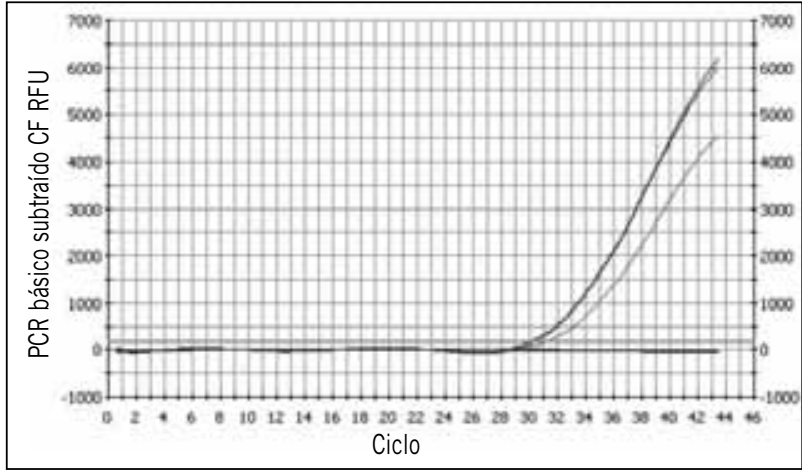

Figura - Curva padrão obtida das amostras amplificadas por RT-PCR para o gene endógeno GAPDH

A curva preta corresponde à amostra obtida pelo protocolo 1; as curvas cinza escuro e cinza claro correspondem às duas amostras obtidas pelo protocolo $2 \mathrm{em}$ diferentes concentrações. As amostras não amplificadas (linha reta) foram obtidas pelo método Trizol.

RT-PCR: reação em cadeia da polimerase em tempo real; GAPDH: gliceraldeído-3 fosfato desidrogenase.

Resolvemos descrever nossos resultados em face da escassez da literatura sobre esse assunto (fato que nos levou a gastar cerca de oito meses no processo de padronização da extração de RNA de amostras FFEP). Usualmente, os artigos publicados com enfoque em análise de expressão gênica a partir de amostras de RNA obtidas de material FFEP não são claros em relação à metodologia de extração utilizada. Alguns deles mencionam extração eficaz pelo método de Trizol(5), entretanto, em nosso estudo, esse método não foi satisfatório, pois não produziu RNA capaz de ser amplificado. Possivelmente, o RNA obtido por esse método estava danificado estruturalmente ou quimicamente ou, ainda, contaminado por substâncias teciduais.

A substituição da formalina por outros fixadores como Bouin, Carnoy, acetona, álcool e hepes glutamic acid buffer-mediated organic solvent protection effect (HOPE) seria uma alternativa para a conservação do $\mathrm{RNA}^{(8,9)}$. Porém, como a formalina é o fixador de escolha da maioria dos centros ao preservar a morfologia e as proteínas celulares, vários grupos têm procurado desenvolver formas de reverter as modificações químicas e estruturais do RNA induzidas por esse fixador ${ }^{(3,8)}$.
Hamatani et al. ${ }^{(4)}$ observaram que parte dessas alterações produzidas no RNA poderiam ser revertidas pela incubação da amostra em tampão TE (pH 7) a $70^{\circ} \mathrm{C}$ por 1 hora. Esse preaquecimento foi utilizado por longo tempo, entretanto os mesmos autores verificaram que $o$ aquecimento das amostras acima de $80^{\circ} \mathrm{C}$ por 30 minutos promove degradação do RNA. Por outro lado, Li et al.(7) descreveram que a temperatura ideal de incubação para retirar as bandas de proteínas interligadas ao RNA e manter sua integridade era de $70^{\circ} \mathrm{C}$ por 20 minutos $^{(4,7)}$. O pH obtido com tampão citrato entre 3 e 6,5 aumentou a eficiência da amplificação do RNA adquirido de amostras FFEP por RT-PCR, enquanto tampões com $\mathrm{pH}$ entre 9 e 10 reduziram a eficiência da amplificação(4).

Em nosso estudo, utilizamos condições e equipamentos adequados, livres de ribonucleases. De cada amostra foram utilizados três cortes de $10 \mu \mathrm{m}$ em todos os protocolos, pois essa quantidade mínima de tecido resultou em quantidade de RNA adequado para PCR. Além disso, o protocolo do kit da Ambion preconiza como suficiente para a recuperação de microRNA (miRNA) cortes de espessura de $10 \mu \mathrm{m}$. Observamos, ainda, que a eficiência da extração de RNA foi superior quando realizada pouco tempo após a obtenção dos cortes.

A etapa de desparafinização com xilol é sugerida por vários autores e na maioria dos kits específicos para amostras FFEP, pois a retirada incompleta da parafina pode resultar em RNA de qualidade inferior ${ }^{(8)}$. A incubação das amostras com xilol com aquecimento preconizado nos protocolos 1 e 3 ou em TA nos protocolos 2 e 3 não evidenciaram diferenças quantitativas ou qualitativas significantes no RNA extraído, mas facilitou a formação do pellet e o consequente manuseio da amostra.

A etapa de reidratação remove o xilol remanescente da etapa de desparafinização, mas a ausência de reidratação preconizada no protocolo 2 não interferiu na qualidade e na amplificação do RNA extraído por PCR, corroborando o descrito por Körbler et al. que não observaram diferenças significantes quanto a realização ou não da etapa de reidratação(5). 
A proteinase K é utilizada em todos os protocolos para remover as proteínas interligadas ao RNA. De acordo com Ribeiro-Silva e Garcia, o calor pode ser um dos responsáveis por reverter parte das alterações químicas induzidas pela formalina ${ }^{(8)}$.

Apesar de ter produzido grandes quantidades de RNA suficientes, o método do Trizol resultou em RNA com grau de pureza inferior e não foi amplificado. Isso ratifica os resultados de Witchell et al.(9), que também não conseguiram amplificar o RNA extraído pelo método do Trizol obtido de amostras FFEP. Contudo, nossos resultados não confirmaram os dados obtidos por Körbler et al. ${ }^{(5)}$.

O sucesso alcançado com os protocolos 1 e 2 corroboram os resultados de Li et al.(7), os quais observaram que protocolos baseados na digestão com proteinase $\mathrm{K}$, seguidos de tratamento com DNAse, purificação em coluna e eluição do RNA, produziram bons resultados em amostras FFEP. Os mesmos autores demonstraram que 0 papel da proteinase $\mathrm{K}$ foi essencial para degradar proteínas covalentemente ligadas entre si, para a liberação do RNA da matriz celular e para inativar RNAses que tendem a ser estáveis.

\section{Conclusão}

Os resultados obtidos por meios dos protocolos usando os kits Ambion (protocolo 1) e Arcturus Bioscience (protocolo 2) foram eficientes para obtenção de RNA suficiente $e$ de qualidade adequada para estudos de expressão gênica a partir de amostras FFEP. O método de Trizol não produziu resultados satisfatórios.

\section{Agradecimentos}

Agradecemos à empresa Applied Biosystem pela colaboração com o nosso estudo mediante o fornecimento do kit RecoverAll Total Nucleic Acid Isolation Optimized for FFPE Samples (Ambion, Inc, Austin, Texas, EUA).

\section{Referências}

1. CHEN, J.; BYRNE JR, G. E.; LOSSOS, I. S. Optimization of RNA extraction from formalin-fixed, paraffin-embedded lymphoid tissues. Diagn Mol Pathol, v. 16, n. 2, p. 61-72, 2007.

2. CHOMCZYNSKI, P.; SACCHI, N. Single step method of RNA isolation by acidic guanidium thiocyanatephenol-chlorophorm extraction. Anal Biochem, v. 162, p. 156-9, 1988.

3. DOLESHAL, M. et al. Evaluation and validation of RNA extraction methods for MicroRNA expression analyses in formalin-fixed, paraffin-embedded tissues. Journal of Molecular Diagnostics, v. 10, n. 3, p. 203-11, 2008.

4. HAMATANI, K. et al. Improved RT-PCR amplification for molecular analyses with long-term preserved formalin-fixed, paraffin-embedded tissues specimens. J Histochem Cytochem, v. 54, n. 7, p. 773-80, 2006.

5. KÖRBLER, T. et al. A simple method for RNA isolation from formalin-fixed and paraffin-embedded lymphatic tissues. Experimental and Molecular Pathology, v. 74, p. 336-40, 2003.

6. LEHMANN, U.; KREIPE, H. Real-time PCR analysis of DNA and RNA extracted from formalin-fixed and paraffinembedded biopsies. Methods, v. 25, p. 409-18, 2001.

7. LI, J. et al. Improved RNA quality and TaqMan ${ }^{\circledR}$ Preamplification method (PreAmp) to enhance expression analysis from formalin fixed paraffin embedded (FFPE) materials. BMC Biotechnology, v. 8, p. 1-11, 2008.

8. RIBEIRO-SILVA, A.; GARCIA, S. B. Estudo comparativo de três diferentes procedimentos para extração de RNA a partir de amostras fixadas em parafina e embebidas em parafina. J Bras Patol Med Lab, v. 44, n. 2, p. 123-30, 2008.

9. WITCHELL, J. et al. RNA isolation and quantitative PCR from HOPE- and formalin-fixed bovine lymph node tissues. Pathology: research and practice, v. 204, p. 105-111, 2008.
Endereço para correspondência

Cisele Rodrigues Couveia Hospital das Clínicas da FMUSP Laboratório de Imunopatologia Av. Dr. Enéas Carvalho de Aguiar, $155 / 1^{\circ}$ andar Cerqueira César

CEP: 05403-000 - São Paulo-SP e-mail: gisele.gouveia@usp.br 